\title{
The Limits of Decolonization: American Occupiers and the “Korean Problem" in Japan, 1945-1948
}

Matthew R. Augustine*

\section{Introduction}

Why is decolonization often said to have been incomplete or even an outright failure in South Korea? ${ }^{1}$ Conventional answers to this question range from the inability of the postcolonial leadership to prosecute proJapanese collaborators to the early Republic's unsuccessful diplomatic efforts to win reparations from Japan. While such explanations are historically grounded and easy enough to understand, they tend to ignore the complex dynamics that characterized decolonization in South Korea. This complexity derives from the fact that Korean and Japanese officials have never engaged in direct negotiations over how to reach a postcolonial settlement, unlike what followed the breakup of many European colonies. Instead, the problem of how to dissolve Japanese colonial rule in the southern half of the divided Korean peninsula was indirectly addressed by external mediators; namely, the US Army Military Government in Korea (USAMGIK) and the Supreme Commander for the Allied Powers (SCAP)

\footnotetext{
* Associate Professor, Faculty of Social and Cultural Studies, Kyushu University

1 Although scholars in different fields of study have variously defined decolonization, I use the term objectively to describe the historical process of dissolving colonial rule, leading to the former colony gaining national sovereignty.
} 
in Japan. Reexamining decolonization must therefore take into consideration how this process was initially mediated, not between the former colonizers and colonized, but instead by the new American occupiers.

Historians and other social scientists have examined separately the US occupations of southern Korea and Japan, but few have attempted an integrated history of the American interlude in East Asia. In his Pulitzer Prize-winning study of occupied Japan, John Dower writes that after 1945 the once aggressively imperial Japan withdrew from the world into an "embrace with its American conquerors." 2 As insightful as this metaphor is, neither national nor binational approaches alone are sufficient to explain how Japan withdrew from its empire in East Asia. Andre Schmid has written that a move away from Japan's "island history" of the past to a transnational history that integrates relations with its colonies "offers a valuable means of reexamining some of the unquestioned parameters of Japanese history." 3 Schmid was concerned primarily with inserting colonialism into Japanese historiography, but the same logic can be applied to a transnational study on the dissolution of the Japanese empire. Recent scholarship has begun to explore the political and social history of decolonization as a mutually constitutive process that reshaped both USoccupied Korea and Japan. ${ }^{4}$ I argue that this integrated history of decolonization must begin, first and foremost, by evaluating inter-occupation relations, focusing on the interaction between USAMGIK and SCAP and why they were unwilling or unable to eliminate vestiges of Japanese colonialism.

2 John W. Dower, Embracing Defeat: Japan in the Wake of World War II (New York: W. W. Norton \& Company, 1999), 22-23.

3 Andre Schmid, "Colonialism and the 'Korea Problem' in the Historiography of Modern Japan: A Review Article," The Journal of Asian Studies 59-4 (November 2000): 973.

4 See Deokhyo Choi, "Crucible of the Post-Empire: Decolonization, Race, and Cold War Politics in U.S.-Japan-Korea Relations, 1945-1952” (PhD diss., Cornell University, 2013); Lori Watt, "Embracing Defeat in Seoul: Rethinking Decolonization in Korea, 1945," The Journal of Asian Studies 74-1 (February 2015): 153-174. 
In order to provide concrete substance to understanding how decolonization was compromised in part by evolving and competing American occupation policies, this article examines three interrelated issues that greatly affected people who found themselves displaced by the sudden termination of the Japanese empire: repatriation, restitution, and nationality. While these issues concerned all such "displaced persons" in USoccupied territory, focusing on Korean migrants in occupied Japan perhaps most vividly illustrates the limits of decolonization. SCAP and USAMGIK actively supported repatriation as the most straightforward demographic solution to decolonization, though disagreements over related regulations reflected significant problems faced by Koreans in occupied Japan. The restitution of financial assets and personal property belonging to Korean repatriates emerged as another challenging issue, testing both the will and the capacity of the two occupation administrations to collaborate in resolving. SCAP's evolving policy towards Korean nationality, corresponding to its increasing efforts aimed at pressuring as many Koreans as possible to repatriate, resulted in an open conflict with USAMGIK. The extent to which US occupation authorities in Korea and Japan jointly engaged in each of these critical issues helped shape the Korean community in postwar Japan, making this human dimension of decolonization more salient than other institutional or cultural dimensions.

\section{Repatriation as Decolonization}

An historical examination on how SCAP and USAMGIK set about dismantling Japanese colonial rule in Korea must begin, briefly, by measuring wartime plans for military occupation with specific policies adopted after the war. The US government's plans for the liberation of Korea and the establishment of a multilateral trusteeship in preparation for the country's eventual independence were first spelled out in May 1943.

5 T 316, "Korea: Territorial and Frontier Problems," May 25, 1943; T 319, "Korea: 
Beyond such fateful policy decisions, during the last months of the war the State Department's Inter-Divisional Area Committee on the Far East considered more practical problems that American authorities would have to address in occupied Korea. This effort led to drafting a series of policy proposals on Korea after liberation, including one specifically regarding Koreans in Japan. Entitled "Koreans Outside Korea: Repatriation of Koreans in Japan," it predicted "racial and political animosity between Japan and Korea would necessitate the departure of Koreans from Japan for their own protection and for the maintenance of peace and order." At the same time, the Office of Strategic Services (OSS) drafted a Civil Affairs Guide entitled "Aliens in Japan," which suggested that Koreans in particular, "may be in urgent need of liberation, protection, or segregation from the Japanese."7 This Guide provided specific recommendations for the military government to follow, beginning with the establishment of a displaced persons division with a repatriation section and a protection section under its authority. It further advised that the repatriation section could immediately secure information on the number and location of foreigners in Japan, registering all non-Japanese civilians in order to arrange for their repatriation. ${ }^{8}$ Meanwhile, the US government created the StateWar-Navy Coordinating Committee (SWNCC) in December 1944, integrating political and military plans for postwar occupations by facilitating

Problems of Independence," May 26, 1943. Copies of these documents can be found in Makoto Iokibe ed., The Occupation of Japan, Part 1: U.S. Planning Documents, 1942-1945 (Congressional Information Service and Maruzen Publishing Co., 1987), 1-B-3; 1-B-4.

6 "Korea: Koreans Outside Korea: Repatriation of Koreans in Japan" (July 6, 1945), 7. The Records of the Office of Assistant Secretary and Under Secretary of State Dean Acheson, 1941-48. [National Archives and Records Administration (hereafter NARA), Record Group 59, Box 12]

7 Office of Strategic Services, "Civil Affairs Guide: Aliens in Japan" (29 June 1945), 29. [GHQ/SCAP Records, National Diet Library (hereafter NDL) in Japan, ESS 12322-12324]

8 Office of Strategic Services, “Civil Affairs Guide: Aliens in Japan,” 30-31. 
the exchange of information and ideas. Such a proactive realignment to improve coordination and integration help explain the consistency of recommendations found in the State Department's policy proposals and the OSS Guide.

Were the specific measures spelled out in the State Department's policy proposals on Korea and the OSS Guide on aliens in Japan, in fact, adopted as official US occupation policy after the war? Was the SWNCC's spirit and practice of wartime cooperation maintained by American authorities in occupied Japan and Korea? In order to answer these questions, SCAP's repatriation policy must be examined first, since this was the primary solution that wartime planners offered to address problems involving Koreans in Japan. Preparing to repatriate over two million Koreans in Japan was a massive task that could not be undertaken without active assistance from local authorities in Korea. Furthermore, the repatriation of Koreans was not intended to occur in a vacuum; rather, it was to be coordinated simultaneously with the repatriation of an estimated 600,000 Japanese from southern Korea, ${ }^{9}$ not to mention hundreds of thousands more crossing over the 38th parallel from northern Korea and Manchuria. USAMGIK's role in implementing this mass repatriation program therefore constitutes an important part of this analysis, along with its involvement in the process of policy planning and adoption.

The State Department's policy proposal, "Repatriation of Koreans in Japan," advised specifically that the occupying forces in Japan plan for a repatriation program in cooperation with the administrative authority in Korea. ${ }^{10}$ However, since this wartime policy document was intended primarily to aid American authorities in occupied Korea, SCAP was unlikely to have observed its recommendations very closely. The OSS Civil Affairs Guide, "Aliens in Japan," on the other hand, was designed to aid

9 Morita Yoshio, Chōsen shūsen no kiroku: Bei-So ryōgun no shinchū to Nihonjin no hikiage (The Occupation of US and Soviet Army and Japanese Repatriation) (Tokyo: Gennandō Shoten, 1967), 328.

10 "Korea: Koreans Outside Korea: Repatriation of Koreans in Japan," 8. 
officers responsible for military government. The preliminary draft of "Aliens in Japan" specifically noted that the recommendations in this and other Guides were not intended to take the place of plans that would be prepared in occupied territory. The final version distributed after the war also stated any persons using the document were to be cautioned that its recommendations were written prior to the Japanese surrender, and thus must be "critically examined in light of current United States policy." In other words, the military government in Japan was to follow basic policies outlined by the US government, while civil affairs officers were expected to form and execute plans for specific tasks as they saw fit. Since the US government ultimately decided against direct military rule in Japan, SCAP's occupation policies including the repatriation of foreigners were to be implemented through the Japanese government, not by the military government. As a result, Japanese authorities knew nothing about the OSS proposal to actively assist Koreans to repatriate while protecting those who wished to remain in Japan, recommendations that were largely ignored in the early months of the occupation.

In the meantime, the recommendations outlined in the State Department's policy proposal and the OSS Guide both appear to have been largely adopted and implemented by US occupation authorities in Korea shortly after liberation. Since USAMGIK established direct military rule to replace the Japanese colonial administration in Korea, policy measures and proposals specifically designed for military government proved particularly useful. Furthermore, considering the relative dearth of detailed plans for occupying Korea, in contrast to those prepared for occupying Japan, US authorities deployed on the peninsula welcomed these concrete recommendations. On September 10, 1945, just two days after assuming control of southern Korea, USAMGIK's Bureau of Planning proposed a tentative repatriation plan to supervise Japanese organizations that were aiding Japanese to return to their homeland. This plan also called for coordination between the US Army's XXIV Corps in Korea and the Eighth Army stationed in Japan to care for and transport Korean repatriates, as proposed by the State Department's policy proposal. Two weeks later, 
overall responsibility for repatriation was transferred to USAMGIK's Office of Foreign Affairs, which directed Lieutenant William J. Gane to investigate the refugee situation in Korea, China, and Japan. Lieutenant Gane's study served as the basis for planning a mass repatriation program capable of helping an estimated 5 million people throughout the region to return to their respective homelands. ${ }^{11}$ The Office of Foreign Affairs subsequently created a Displaced Persons Office to handle incoming Korean repatriates as well as outgoing foreigners, thus following the OSS Guide to the letter.

Occupation policy towards Koreans in Japan was first addressed as a part of the "Basic Initial Post-Surrender Directive" that the SWNCC issued to SCAP in November 1945. This document directed SCAP to treat Koreans and Formosans as "liberated peoples," who should not be included in the term "Japanese" as used in the directive. It also stipulated, "they may be repatriated, if they so desire, under such regulations as you may establish."12 More than two months after Japan's surrender, SCAP belatedly began planning for an organized repatriation of liberated Koreans, instead of continuing to rely on Japanese authorities to handle this challenging task. Although SCAP subsequently issued a comprehensive directive to the Japanese government dealing with the repatriation of socalled "non-Japanese," USAMGIK officials reported persistent problems of coordination with their counterparts in Japan. For example, William Gane noted that the Office of Foreign Affairs sent several requests to SCAP to have Korean repatriates loaded at Japanese ports according to their ultimate destination in Korea, requests that were rejected for un-

11 For further details on displaced persons and their repatriation, see William J. Gane, "Foreign Affairs of South Korea, August 1945 - August 1950" (PhD diss., Northeastern University, April 1951): 17-30.

12 "Basic Initial Post-Surrender Directive to Supreme Commander for the Allied Powers for the Occupation and Control of Japan," 1 November 1945 (SWNCC 52/7), in Government Section, Supreme Commander for the Allied Powers, Political Reorientation of Japan, September 1945 to September 1948 (Washington, D.C.: Government Printing Office, 1949), 428-429. 
known reasons. ${ }^{13}$ Broadly speaking, these problems of coordination were inherent in the organization of the two American Occupations. Edward W. Wagner, who was also employed by USAMGIK's Office of Foreign Affairs, maintained that the essential duality between the political and military structures of the Occupation in southern Korea was perhaps its most conspicuous feature. ${ }^{14}$ Unlike the dual structure in occupied Japan, the headquarters of the central military government based in Seoul was subordinate to the XXIV Corps that occupied all of southern Korea. This meant that officers like Wagner and Gane in the Office of Foreign Affairs had to go through multiple military channels of communication between Korea and Japan, often causing delays in repatriation.

The Allied repatriation program remained unchanged until another SWNCC directive communicated to SCAP in December 1945 clarified the US government's policy regarding aliens in Japan. Based on the SWNCC's earlier "Basic Directive" that designated Korean and Taiwanese in Japan as liberated nationals, this directive maintained that they were "displaced persons" who should be repatriated to where they belonged. Although such displaced persons were given the choice of repatriating or not, Occupation authorities were directly responsible for guaranteeing their security and welfare. ${ }^{15}$ This directive, coupled with the overall decline in the number of Koreans repatriating through officially designated reception centers, forced SCAP to convene a conference to address these issues. Occupation authorities representing various departments from SCAP, the Eighth Army, USAMGIK, and XXIV Corps attended the repatriation conference held in Tokyo between January 15-17, 1946. The three-day conference resulted in an expedited program of repatriation, mainly by increasing the number of available American Liber-

13 Gane, "Foreign Affairs of South Korea," 134-136.

14 Edward W. Wagner, The Korean Minority in Japan, 1904-1950 (New York: Institute of Pacific Relations, 1951), 73.

15 “U.S. Policy Regarding Displaced Persons in Japan," December 5, 1945 (SWNCC 205/1). 
ty Ships and recommissioned LST's. Shipping in the Japan-Korea shuttle and Japan-Korea-China shuttle was thus set up to handle a maximum of 10,500 Koreans per day. ${ }^{16}$

The representative of USAMGIK who attended the repatriation conference in Tokyo was highly critical of how US Occupation forces treated Koreans in Japan. Captain Robert L. Beyer, chief of USAMGIK's Displaced Persons Office, was disturbed by what he discovered during his visit in January 1946 to the headquarters of SCAP and the Eighth Army, as well as to the regional ports of Hakata and Sasebo. Upon returning to Seoul, Beyer filed a report claiming that almost everywhere in Japan he found that US officers having anything to do with Korean repatriation were either prejudiced against Koreans or were indifferent to them. ${ }^{17}$ In a subsequent report, he elaborated on the widespread attitude of such officers who viewed Koreans as "headaches" that caused "unnecessary annoyances." Such negative attitudes towards Koreans in occupied Japan may have resulted from reports and encounters with Koreans who refused to obey Japanese officials and regulations after liberation. At the same time, they also reflected an increasing tendency among American occupiers to adopt and reiterate Japanese discriminatory views, thus contributing to the designation of this unwanted minority group as the "Korean problem" in Japan. In order to combat such views in accordance with the SWNCC directives to SCAP, Beyer recommended that "all officers and men in Japan should be instructed to treat Koreans there as liberated people and in a generous spirit." 18

Captain Beyer's critical report indicates that the US military personnel's prejudiced attitude and unsympathetic treatment of Koreans in Japan

16 "Repatriation and Koreans Affairs in Japan," a confidential report from Captain Robert L. Beyer to the Chief of Foreign Affairs Section, USAMGIK, dated February 5, 1946. [Record Group 332, Box 33, NARA]

17 "Korean Repatriation from Japan," a message from Captain Robert L. Beyer to Lt. Col. Gordon B. Enders, USAMGIK, dated February 3, 1946. [Record Group 332, Box 33, NARA]

18 Beyer, "Repatriation and Koreans Affairs in Japan," February 5, 1946. 
translated into a policy of strongly encouraging them to leave Japan without providing incentives to do so. As Beyer correctly pointed out, strict regulations that prohibited repatriates from taking more than $¥ 1,000$ in currency and only personal belongings that could be carried on their backs was cutting down on the number of those returning to Korea. ${ }^{19}$ Nevertheless, SCAP's Economic and Scientific Section (ESS) insisted on these restrictive customs regulations in order to prevent the outflow of Japanese currency and other valuables from further destabilizing Japan's economy in the wake of the devastating war. According to one estimate, $¥ 1,000$ at the time was just enough to buy the equivalent of twenty packs of cigarettes and could barely support a family for one week in inflationridden Korea. ${ }^{20}$ In fact, many repatriates, especially those without family or friends that they could depend upon, became welfare cases in Korea. Beyer's report therefore recommended that a more lenient economic policy be adopted to permit Korean repatriates to carry back with them up to $¥ 10,000$ in currency and 150 to 300 pounds of personal effects per person. ${ }^{21}$ This and other recommendations received the strong endorsement of General John Hodge, chief commander of the XXIV Corps, who sent a memorandum to General Douglas MacArthur calling for improvements in the treatment of Koreans in Japan.

SCAP never directly responded to General Hodge's memorandum containing Captain Beyer's recommendations, but instead proposed its own plan for expediting the repatriation of Koreans in Japan. On February 17, 1946, SCAP ordered the Japanese government to register all Koreans as

19 Beyer, "Korean Repatriation from Japan," February 3, 1946. These regulations were spelled out in two SCAP directives to the Japanese government: "Control over Exports and Imports of Gold, Silver, Security and Financial Instruments" (SCAPIN 44), 22 September 1945; and "Supplemental Instructions Relating to Import and Export Controls" (SCAPIN 127), 12 October 1945.

20 Herbert P. Bix, "Regional Integration: Japan and South Korea in America's Asian Policy," in Without Parallel: The American-Korean Relationship Since 1945, ed. Frank Baldwin (New York: Pantheon Books, 1973), 185-186.

21 Beyer, "Repatriation and Koreans Affairs in Japan," February 5, 1946. 
well as Taiwanese, Chinese, and Ryukyuans in Japan within a one-month period in order to determine their desire for repatriation. ${ }^{22}$ This registration included personal information such as name, age, sex, occupation, and place of residence in Japan, in addition to a statement of desire concerning repatriation and destination in their native land if they desired repatriation. Japanese officials were required to inform these minority groups that those registering as not desirous of repatriation, or those who fail to register at the appointed time, would forfeit their privilege of free passage provided by the Japanese government. By March 18, 646,711 Koreans were registered, out of whom 513,900 expressed their desire to repatriate, ${ }^{23}$ thereby providing basic records regarding Koreans in Japan for the first time since the end of the war. The collection of these records, remarkably similar to what the OSS Guide "Aliens in Japan" had called for, may have partially served as a basis for enacting an alien registration in occupied Japan the following year. ${ }^{24}$ For the time being, however, SCAP issued a directive to the Japanese government, which set forth a plan to clear from Japan all those who registered for repatriation. According to this ambitious plan, 3,000 Koreans were to be shipped out each day from the reception center at Hakata, and another 1,000 from Senzaki between April 15 and September 30. ${ }^{25}$

22 "Registration of Koreans, Chinese, Ryukyuans and Formosans" (SCAPIN 746), February 17, 1946.

23 General Headquarters, Supreme Commander for the Allied Powers, History of the Nonmilitary Activities of the Occupation of Japan, Volume VI, Part 4: Treatment of Foreign Nationals (Washington, D.C.: World War II Records Division, National Archives and Records Service, 1952), 18. This figure does not include large numbers of Korean residents who did not register and others who had illegally entered Japan since the end of the war.

24 "Aliens in Japan" called for a registration including information such as their date of arrival in Japan, property ownership, business connections, activities in Japan on behalf of the Japanese and other governments, and desires concerning repatriation. Office of Strategic Services, "Aliens in Japan," 30-31.

25 "Repatriation of Chinese, Formosans, and Koreans" (SCAPIN 876), April 13, 1946. The rate of repatriation and target date for completion contained in this di- 
In principle, the sound and efficient repatriation of Koreans in Japan depended upon the ability of Occupation authorities in southern Korea and Japan to carry out a range of measures that were mutually agreeable to both sides. Although this principle held up for the most part, the hierarchy of the US military command in the two neighboring territories sometimes created tensions that affected the overall pace of repatriation. For example, on May 22, 1946 the XXIV Corps advised SCAP to temporarily suspend repatriation due to serious welfare problems faced by large numbers of Korean repatriates who were unable to find adequate food or employment in southern Korea. ${ }^{26}$ However, SCAP did not approve the suspension of repatriation until June 27 when another urgent request from the XXIV Corps claimed that rail lines and major roads in southern Korea were washed out by severe flooding. ${ }^{27}$ As soon as conditions improved, SCAP resumed the repatriation of Koreans from Japan on August 10, ignoring a plea from the XXIV Corps to postpone repatriation until November 30, due to continuing economic and social problems in southern Korea. This was largely because SCAP and the Eighth Army by this time came to view the continued presence of a "restless, uprooted Korean minority in Japan," disdainful of law and authority, as becoming a "serious obstacle to the success of the Occupation." 28 These occupation authorities therefore attempted to repatriate as many Koreans as possible, and in fact deported many who were convicted of illegal and subversive activities, in order to relieve the burden of the "Korean problem" in Japan.

rective were subsequently amended from time to time.

26 Telegram from XXIV Corps to SCAP, 22 May 1946. [Record Group 332, Box 33, NARA]

27 Outgoing dispatch from CG XXIV Corps to SCAP and SCAJAP, 26 June 1946. [Record Group 332, Box 33, NARA]

28 GHQ/SCAP, History of the Nonmilitary Activities of the Occupation of Japan, 26. 


\section{The Reverse Course on Restitution}

The customs regulations that were implemented as a part of the mass repatriation program demonstrated that SCAP was concerned with more than just returning Japanese and non-Japanese to their respective homelands; it also insisted on limiting the flow of their financial assets and personal property in and out of Japan. However, the State Department's "Repatriation of Koreans in Japan" did not even mention the need for such regulations. While the OSS Guide "Aliens in Japan" proposed that the military government's repatriation section make financial arrangements, it did not suggest imposing customs that limited what repatriates could take home with them. Instead, it noted merely that the disposition of foreign property in Japan would likely affect the future plans of foreigners. ${ }^{29}$ Given the absence of specific instructions emanating from Washington, how and why did SCAP and USAMGIK determine what to do with the property and assets of Korean repatriates left behind in Japan? One key to answering this question is to examine the inter-Occupation liaison between American authorities in Japan and Korea over this critical issue of decolonization.

US Occupation authorities first became embroiled in restitution claims after SCAP decided to induce Korean coal miners in Japan to remain at work, according to Edward Wagner, not only to supply Japan but also to meet southern Korea's demands. This inducement came in the form of a SCAP directive in late October 1945, instructing the Japanese government to make immediate arrangements for the periodic collection of savings that Korean miners might desire to remit to Korea. ${ }^{30}$ Yet SCAP's policy of continuing to make use of Korean miners underestimated their overwhelming desire for immediate liberation and repatriation, just as Japanese authorities had already attempted to retain them without much

29 Office of Strategic Services, "Aliens in Japan," 31-33.

30 SCAPIN 207, "Payments of Savings and Allotments in Korea of Korean laborers in Japanese Coal Mines," October 29, 1945. Wagner, The Korean Minority, 49. 
success. Worse still, many of those conscript laborers brought to Japan against their will began to go on strikes, rioting in places like Hokkaidō and Jōban, as they demanded improvements in wages, food rations and working conditions. In order to avoid the further escalation of violence, SCAP belatedly ordered Korean miners to be released and repatriated, unaware initially that many of the Japanese corporations never paid them their wages, savings, and pensions. ${ }^{31}$ But in the face of increasingly vociferous calls from repatriated laborers in Korea demanding compensation from Japanese corporations, SCAP decided to collect the assets for eventual repayment. On March 1, 1946 American Occupation authorities established the "Custody Account of the Supreme Commander for the Allied Powers" with the Bank of Japan in Tokyo and ordered corporations to begin depositing unpaid funds into this account. ${ }^{32}$ The management of the SCAP Custody Account was entrusted to the Civil Property Custodian (CPC) Section. The CPC's main responsibility was to advise SCAP on the disposition of property and assets in Japan belonging to the Allied powers, enemy nations and former Japanese colonies, which included the SCAP Custody Account. ${ }^{33}$

US Occupation authorities deployed in Hokkaidō prefecture were the first to collect the unpaid wages, savings and pensions owed to Korean conscript laborers. On May 5, 1946, the Headquarters of the 74th Military Government Company transmitted to the Commanding General of the Eighth Army a report on the unsettled accounts of Korean laborers who were repatriated from Hokkaidō. The report described how most of the 108,400 Koreans in Hokkaidō were "slave laborers who revolted en masse against Japanese domination," necessitating their repatriation. In some cases, they were repatriated "forcibly with the understanding that a

31 For a further description of Korean miners and their grievances against their Japanese employers, see Gane, "Foreign Affairs of South Korea," 127-128.

32 SCAP, "Summation of Nonmilitary Activities in Japan, No. 6," March 1946.

33 Eiji Takemae, Inside GHQ: The Allied Occupation of Japan and its Legacy (New York: Continuum, 2002), 196. 
later settlement would be handled through representatives of a Korean Government." ${ }^{34}$ Attached to the report was an itemized list of 21 checks that were impounded from companies and government agencies that employed Korean laborers in Hokkaidō. While a majority of these funds were collected from mining and electric companies, two checks were from the Japanese Demobilization Bureau to cover funerary expenses and the delivery of ashes belonging to Korean laborers who were killed. Some companies also wrote checks covering death benefits, while others covered injury compensation, back wages, and bonuses for laborers who had been repatriated to Korea. The 74th Military Government continued to collect funds owed to Korean conscript laborers until the total amount reached over $¥ 2.5$ million by August. ${ }^{35}$

What happened, then, to the Korean funds from Hokkaido after the 74th Military Government deposited them into the SCAP Custody Account in Tokyo? The restitution of these funds, just like the mass repatriation program, depended on SCAP's ability to cooperate and coordinate effectively with the XXIV Corps and USAMGIK. On May 27, 1946, Lt. Col. McDiarmid from ESS, SCAP visited representatives of USAMGIK in Seoul to discuss the formulation of a policy for transmitting the funds. A general agreement was subsequently reached whereby USAMGIK's Department of Finance would pay Korean beneficiaries in Bank of Chosen notes, as soon as the original records listing individual addresses and amounts owed were received from Hokkaidō. ${ }^{36}$ Based on these arrange-

34 74th Military Government Company to Commanding General, Eighth Army, "Funds Consisting of or Pertaining to the Unsettled Accounts of Koreans who have been Repatriated from Hokkaido," 5 May 1946, p.2. [Record Group 331, Box 3713, NARA]

35 The total amount of $¥ 2,554,427.81$ through August 1946 is listed in a CPC document, "SCAP Custody Account - Bank of Japan, Koreans (Repatriated)." [CPC17939, NDL].

36 Memo for the record regarding subject, "Funds Consisting of or Pertaining to the Unsettled Accounts of Koreans Who Have Been Repatriated from Hokkaido." Undated. [CPC-08855, NDL] 
ments, on May 31 SCAP directed the XXIV Corps to pay the collected sum of savings and allotments owed to repatriated Korean laborers. The XXIV Corps was then expected to inform SCAP when payment was effected, so that the SCAP Custody Account could be debited accordingly.

However, the SCAP Custody Account was never debited because the XXIV Corps failed to disburse the funds to the rightful beneficiaries in Korea. In mid-1947, more than a year after SCAP's disbursement directive, an official from the CPC's External Assets Branch visited Korea to discuss the matter with representatives of USAMGIK. Edward Wagner, who had by then become an advisor to USAMGIK's Japanese Affairs Section, promised to investigate why the payment of Korean funds had not been effected in Korea. In a subsequent letter that revealed the main impediment preventing restitution, Wagner raised a simple yet critical question: Was it really advisable to settle the claims of Korean repatriates from Hokkaidō without definite assurance that payment of hundreds of other claims, identical in nature, would be authorized ${ }^{37}$ In other words, Wagner was essentially warning CPC that the disbursement of the Hokkaidō funds could open up the floodgates of individual claims that USAMGIK was not prepared to handle. ${ }^{38}$ The CPC was not in a position to enforce restitution from other prefectures, either, especially since the Japanese government had by then succeeded in preventing the Hokkaidō case from setting a national precedent. The government did so by ordering Japanese corporations to deposit all unpaid wages and other financial assets of Korean and Chinese laborers into bank accounts administered by the attorney general's office in prefectural governments. By scattering these assets into regional bank accounts, the government avoided the

37 CPC External Assets Branch, "Conference Report," 22 September 1947. [CPC08856, NDL].

38 The XXIV Corps also experienced considerable difficulty in locating beneficiaries in Korea based on the reports provided by the Japanese coal mine operators. See CPC memo for the record, subject: "Deposits of Korean Coal Miners in the Bank of Japan,” 6 December 1946. [Record Group 331, Box 3660, NARA] 
same funds from ending up in the centralized SCAP Custody Account for eventual disbursement to Korea. ${ }^{39}$ The CPC thus ultimately concurred with Wagner, deciding not to persist on the restitution of the Hokkaidō funds at this time, as the unpaid wages, savings, and pensions of Korean conscript laborers remained in the SCAP Custody Account.

The unresolved issue of Korean funds in Japan proved impossible for American occupation authorities in Korea to ignore for very long. As long as Korean leaders led by Syngman Rhee persistently demanded individual restitution as well as national reparations from Japan, USAMGIK as the governing authority in southern Korea was compelled to support a broad range of Korean claims against Japan. ${ }^{40}$ Based on the US government's initial reparations policy that indicated Korea might be eligible for reparations, USAMGIK in 1946 had established a Special Economic Committee that prepared lists of Korean claims and Japanese counterclaims, including compensation for lost and confiscated personal properties. The Committee calculated that Korean claims upon Japan amounted to over $¥ 49$ billion, which was $¥ 40$ billion more than the estimated Japanese claims upon Korea. ${ }^{41}$ USAMGIK expected the Japanese government to pay this balance, pending a final decision regarding Korean eligibility for repara-

39 For further details on Korean funds in the SCAP Custody Account, see Matthew R. Augustine, "Restitution for Reconciliation: The US, Japan, and the Unpaid Assets of Asian Forced Mobilization Victims," The Journal of Northeast Asian History 81 (Summer 2011): 5-37.

40 Reparations primarily refers to a defeated nation's indemnity payment for damages caused by war, whereas restitution is defined as an act of restoring to the rightful owner something that has been taken away, lost, or surrendered. Elazar Barkan explains that restitution is a useful concept that includes legal, political, and cultural attempts to rectify historical injustices, contrasting it with war reparations defined as enforced retribution. Elazar Barkan, The Guilt of Nations: Restitution and Negotiating Historical Injustices (New York: W.W. Norton \& Company, 2000), xviii xxvi.

41 A breakdown of Korean claims and Japanese claims, compiled by the Director of the Bank of Korea, can be found in Robert T. Oliver, Why War Came in Korea (New York: Fordham University Press, 1950), 244-245. 
tions. In the meantime, USAMGIK in 1947 designated the National Economic Board as the official liaison between the United States Reparations and Restitutions Delegation in Tokyo and the various USAMGIK departments in Seoul. ${ }^{42}$ Their cooperation with the Reparations and Restitutions Delegation reflected USAMGIK's support for brokering a postcolonial settlement between Korea and Japan over outstanding claims.

With the impending end of its tenure as the occupation administration in southern Korea, USAMGIK renewed its call for mediating a settlement between Japan and Korea. On May 15, 1948, three months before the inauguration of the Republic of Korea, USAMGIK drafted a thirty-page study on how best to handle Korean claims against Japan. ${ }^{43}$ Beginning with a general discussion on the background of these claims, including governmental and private claims, the study described broad categories of claims, giving examples and indicating a means of processing them. One such category was claims of Korean individuals based on unhonored contracts, specifically citing the example of repatriated Korean miners employed by Japanese mining companies in Hokkaidō for unpaid wages, benefits and allowances. Another category was claims of Korean individuals to their bank accounts in Japan, citing many examples of Korean miners and other laborers for assets they left on deposit when they repatriated to Korea. These were but a few of many cases with records that USAMGIK had on file, specific claims that it hoped to settle since the funds in question were already deposited in the SCAP Custody Account. In addition, there was yet another category of claims for assets due from the Japanese Army, Navy, and related government agencies for labor performed outside of Korea. With examples of claims from Korean associa-

42 Sung-Hwa Cheong, The Politics of Anti-Japanese Sentiment in Korea: JapaneseSouth Korean Relations under American Occupation, 1945-52 (Westport: Greenwood Press, 1991), 55.

43 "Claims of the Korean Government, Government Departments, Bureaus and Agencies, Korean Individuals and Juridical Persons Against the Japanese Government, Japanese Individuals and Juridical Persons." [Record Group 332 Box 34, NARA] 
tions in Thailand, Malaya and Singapore, USAMGIK recognized the right of former Korean military conscripts to demand restitution for their unpaid wages, bonuses and retirement benefits, funds that were not yet on deposit in the SCAP Custody Account.

On the basis of this study, USAMGIK's Claims Advisory Board proposed a set of concrete recommendations. The first two were procedural recommendations, namely to select a group of American attorneys most familiar with claims in Korea who would travel to Japan to deliver this detailed report and discuss it with SCAP representatives. In the meantime, the Advisory Board recommended USAMGIK to designate a few American attorneys to organize a central commission to process these claims, working together with representatives of the future Korean government. Former conscript laborers - both corporate and military - would thus be able to file their claims to this commission, which would compile full documentation before forwarding their claims to SCAP for presentation to the appropriate Japanese government agency. Any assets recovered through diplomatic channels would then be distributed to the individuals by the commission. As this proposed program for the liquidation of claims progressed, the Advisory Board envisioned the US-led commission to be reorganized as a joint Korean-Japanese claims commission. ${ }^{44}$ Fully aware of the complicated problems and diplomatic sensitivities involved in such claims, USAMGIK nevertheless requested SCAP's active participation in this proposed program for overseeing an ultimate settlement.

By this time, however, the US government was in the process of reversing its occupation policy towards Japan, abandoning the earlier pursuit of war reparations in favor of focusing on economic recovery. Following this "reverse course," SCAP was unwilling to commit to USAMGIK's request for settling Korean claims, which detracted attention from its new goal of rebuilding Japan's economy in the face of heightening cold-war tensions in the region. On the other hand, ESS,

44 Ibid., 29. 
SCAP did agree to transfer a portion of Korean funds in the SCAP Custody Account, in accordance with the initial financial and property settlement entered into between the US and the newly established Republic of Korea. This portion was restricted, specifically, to the aggregate amount of the $¥ 1,000$ that individual Koreans were permitted to exchange at the repatriation ports, as well as all currency in excess of this limit, which had been deposited into the Custody Account. In November 1948, SCAP directed the Japanese government to effect the transfer of these funds, which by then amounted to over $¥ 31$ million, to the South Korean government. ${ }^{45}$ While other categories of Korean funds remained in the Custody Account, they were much smaller in value, often with incomplete or unreliable records, factors that led ESS to believe that their restitution was not such an urgent matter. Ultimately, SCAP reversed course on its restitution policy, preferring the ultimate disposition of Korean funds in Japan to be determined on a bilateral basis, thus parting with USAMGIK's plans for mediating a postcolonial settlement.

\section{The Illusion of Nationality}

While SCAP and USAMGIK fundamentally agreed on the need for repatriation, and only belatedly came to disagree over restitution, the issue of nationality revealed a definite conflict of interest between the two US occupation administrations. This inter-occupation conflict over nationality was not readily apparent at first. One of the State Department's wartime policy proposals specifically raised the possibility of legislating a new Korean nationality, thus giving overseas Koreans the option of applying for and acquiring that nationality. This proposal pointedly avoided the unilateral assignation of Korean nationality, as State Department officials

45 The total amount of $¥ 31,668,854.78$ is listed in SCAPIN 6184-A, "Release of Funds from SCAP Custody Account," November 17, 1948. [CPC-17318, NDL] It should be noted that the ultimate disposition of this sum is unclear. 
believed Koreans abroad should also be free to retain their nationality status, if they wished to do so. ${ }^{46}$ SCAP did not adopt such a policy and avoided clarifying the legal status of former colonial subjects in Japan, treating them both as Japanese and as foreigners, depending on circumstances that it deemed was in the best interest of the Occupation. On the other hand, USAMGIK appeared to follow the State Department's recommendation in January 1946 when it issued a memorandum on the administrative determination of Korean status, pending a definite determination of Korean nationality. According to William Gane, overseas Koreans were granted the full benefits of this Korean status, as long as they were born in Korea of Korean parentage and either emigrated volun tarily or were conscripted during the war. ${ }^{47}$ Examining the reasons for such differing policy approaches between USAMGIK and SCAP can shed light on how this most contentious issue of decolonization affected Koreans in Japan.

When it became clear by the spring of 1946 that the rate of Koreans departing from Japan was sharply declining, SCAP decided to add a conditional clause to their previous designation as liberated people. On May 21 SCAP sent a message to the State Department recommending that Koreans who continued to reside in Japan "will be presumptively considered for the purposes of treatment as retaining their Japanese nationality." The State Department approved this recommendation, including the stipulation that Koreans in Japan would be treated as Japanese nationals until a duly established Korean government accorded them recognition as Korean nationals. SCAP initially chose not to publicize this newly adopted policy in order to avoid any negative impact on its mass repatriation pro-

46 "Korea: Status of Koreans Who Are Citizens of Other Countries," July 11, 1945. [Record Group 59, Box 12, NARA]

47 Foreign Affairs Section, "Staff Memorandum Number 11," January 10, 1946. Gane, "Foreign Affairs of South Korea," 86-87.

48 Outgoing Message from GHQ/SCAP to WARCOS, May 21, 1946. [CIE-04143, NDL] 
gram, which it held out was the best solution to the "Korean problem" in Japan. With the impending termination of this program that still failed to meet its expectations, SCAP finally announced on November 5 and again a week later that unrepatriated Koreans would be regarded as Japanese nationals. These announcements further stated that any such Koreans who forfeited the privilege of repatriation would be denied any related rights and would thus be subject to Japanese laws. ${ }^{49}$ In other words, SCAP had now determined that repatriation was the only guaranteed way for Koreans in Japan to attain liberation from colonial rule.

Although SCAP may have intended these announcements to serve as a final inducement for repatriation, they sparked immediate protests from Korean nationalists in Japan, protests that then spread to the Korean peninsula. The Chosun Ilbo and other major newspapers published articles that decried SCAP's announcement, accusing it of forcibly naturalizing Koreans in Japan against their will, thus violating the SWNCC directive to treat Koreans as liberated people. ${ }^{50}$ The Korean press then requested USAMGIK for a clarification on SCAP's policy, a positive statement on the official stance of American authorities in Korea, and what steps if any would be taken to have this policy rescinded. In response, USAMGIK's Office of Foreign Affairs called an emergency meeting, clearly upset that it had not been consulted for comment prior to SCAP's policy announcement. Col. William F. Centner then sent a confidential message to SCAP's Government Section, pointing out that a successful solution to the nationality problem was vital to the occupation mission in Korea. Specifically, Col. Centner maintained that US commitment to assist Korea in developing an independent government implied American protection of Korean interests and residents abroad. He also warned SCAP of possible "violent repercussions," as "Korean leaders and groups inimical

49 Press Release, "Koreans must report to Reception Center when called or forfeit recognition as Korean nationals," November 12, 1946. [CIE-04145, NDL]

50 See, for example, G-2 Weekly Summary, from 10 to 17 November 1946. [Record Group 332, Box 34, NARA] 
to American authorities in South Korea will use this announcement to make it appear to Koreans both here and in Japan that the Americans have betrayed them." Furthermore, his message pointed out that SCAP's announcement raised numerous legal questions concerning Korean-owned property and assets in Japan, demonstrating how closely nationality was tied to unresolved issues of reparations and restitution. Considering these and other complex problems, Col. Centner proposed that SCAP reconsider and revise its announced policy, in order to better facilitate the aims of the American occupation in southern Korea. ${ }^{51}$ Instead, he suggested that SCAP regard Koreans in Japan as "friendly nationals," pending the establishment of a sovereign Korean state, at which time they "would be given their choice of accepting Korean or Japanese citizenship."

In response, SCAP's Diplomatic Section sent a curt message to USAMGIK, noting only that the Japanese press had misrepresented its announcements on the status of Koreans in Japan, a problem it corrected by issuing a public statement that was quoted in the message. This new statement, dated November 20, revealed that SCAP was clearly on the defensive in the face of widespread criticism in Japan as well as in Korea. In an attempt to set the record straight, the statement began by noting that occupation authorities had always treated Koreans as liberated people, doing everything possible for their welfare. After citing some examples, it then endeavored to clarify its position regarding the legal status of Koreans in Japan, explaining that SCAP had "no intention of interfering in any way with the fundamental rights of any person of any nationality in regard to retention, relinquishment or choice of citizenship." 52 Thus carefully avoiding the appearance of such interference, it nevertheless reiter-

51 Another problem involved unrepatriated Koreans in Japan from northern Korea and whether or not they would also be considered Japanese nationals. Confidential message from Col. William F. Centner, USAFIK, to SCAP (Government Section), November 20, 1946. [Record Group 332, Box 33, NARA]

52 Press Release, "SCAP Spokesman clarifies treatment of Koreans in Japan," November 20, 1946. [CIE-04145, NDL] 
ated its earlier announcement, noting that Koreans refusing repatriation make their choice with full knowledge that continued residence in Japan subjects them to all local laws and regulations. In other words, even liberated people had to observe Japanese laws, as long as they remained in Japan.

Although SCAP's revised statement insisted it continued to treat Koreans in Japan as liberated people, the lack of clarity regarding their legal status failed to appease the storm of Korean nationalism. Pressing home this point in another message sent in early December, Col. Centner insisted SCAP directly address the questions he raised before, noting that Korean leaders and opinion makers were eagerly awaiting answers. ${ }^{53}$ Clearly upset by these persistent requests from a subordinate administration, SCAP nevertheless responded to points it wished to emphasize; namely, that it was treating Koreans in Japan as liberated people, adamant that "there is absolutely no, repeat, no discrimination against Koreans." SCAP also maintained that the issue of nationality had no relation to repatriation, except for Koreans "desiring permanent residency here may himself choose to retain Japanese nationality." 54 Although such statements contradicted actual practice, USAMGIK repeated many of them verbatim during a special press release in Seoul later that month. Asked pointedly if Koreans who did not repatriate would retain their Japanese nationality, USAMGIK's answer was a definite "no," explaining, "Koreans have been liberated from any and all vestiges as subjects, citizens or nationals of Japan." 55 Having clarified SCAP's official position on the subject, USAMGIK officials were reassured that Koreans would no longer be treated as Japanese nationals.

53 Message from Col. Centner, USAFIK to SCAP (Government Section), December 6, 1946. [Record Group 332, Box 33, NARA]

54 Outgoing Message from AG, SCAP to CG, USAFIK, December 16, 1946. [AG03257, NDL]

55 Headquarters, United States Army Military Government in Korea, Department of Publication Information, "Special Press Release," December 28, 1946. [Record Group 332, Box 33, NARA] 
Despite public statements to the contrary, SCAP continued to treat Korean residents as Japanese nationals, as they were subject to Japanese criminal jurisdiction and expected to pay Japanese taxes, just as they were before the end of the war. The announcement that Koreans had to pay a capital tax, coming as it did on the same day of SCAP's controversial announcement on the nationality issue, led to the outbreak of violence that Col. Centner had warned of. Indignant at being treated as Japanese nationals and still more embittered at having to pay taxes for a war they were not responsible for, Korean protestors on December 20 marched to the Japanese premier's residence where a scuffle broke out with the police. This incident, in turn, hardened both American and Japanese attitudes against Koreans in occupied Japan. Upon close consultation with SCAP's Government Section, on May 2, 1947 the Japanese government issued an ordinance requiring all resident aliens to be officially registered and carry documented passbooks. Unlike the repatriation registration, this alien registration was a combination of wartime Japanese and American models, implemented specifically to better monitor and capture illegal and subversive aliens. ${ }^{56}$ Although strong opposition from Korean organizations in Japan delayed its implementation, the alien registration ordinance later served as the basis for Japanese laws that ultimately de-nationalized former colonial subjects.

The alien registration ordinance reopened the unresolved question of how to determine the legal status of Koreans in Japan, a question that USAMGIK began to investigate in earnest. As a part of this effort, USAMGIK's Liaison Office in Osaka requested the legal opinion of Suegawa Hiroshi, a professor of law at Kyoto University. Suegawa's opinion differed slightly from the State Department's wartime policy proposal on the subject, as he argued first that Koreans residing in Korea ceased to be Japanese nationals when Japan accepted the terms of the Potsdam Declaration. He then pointed out that there were two contending

56 For further details on the origins of the alien registration ordinance, see Eiji Takemae, Inside $G H Q, 450-451$. 
schools of thought regarding Koreans abroad: On the one hand, according to the German theory, Koreans automatically lost their Japanese nationality status at the moment that Koreans at home lost theirs; on the other hand, according to the American theory, the nationality status of Koreans in Japan was unaffected by any territorial changes involving Korea. Following the latter example, Suegawa maintained, individuals residing in Japan would have the choice of either changing or maintaining their nationality status, not unlike the recommendation made by the State Department during the war. Based on such legal opinions and recommendations, USAMGIK reaffirmed its own position that the Japanese surrender terminated the obligation of allegiance to Japan on the part of Koreans everywhere. In order to help clarify this important point, in early September USAMGIK's Liaison Office in Tokyo proposed that SCAP issue a press release explaining that Koreans "are nationals of Korea, a liberated country," and "any assumption that Koreans are Japanese nationals is not supportable.",57

Disagreeing with USAMGIK that a clarification on the status of Koreans in Japan would serve US interests, SCAP's Legal Section objected to the basic premise of the proposed press release. Directly contracting SCAP's earlier reassurances to USAMGIK, the Legal Section argued that Koreans technically remained Japanese nationals until the signing of a formal peace treaty with Japan. The Legal Section maintained that this official recognition was particularly important, according to William Gane, since the US could allegedly require Japan to pay for the costs of the Korean occupation "only as long as Korea remained a part of Japan." ${ }^{\text {"58 }}$ Whether this was true or not, USAMGIK took strong exception to this line of reasoning, directly challenging SCAP's position in a legal opinion it prepared in late October. This legal opinion contended that if Korea remained legally a part of Japan, then the Japanese government would have to extend citizenship rights to Koreans, whereas the reality

57 USAMGIK, Legal Opinions, Vol. II (Seoul: USAMGIK, 1948), 376.

58 Gane, "Foreign Affairs of South Korea," 149. 
was exactly the opposite. Furthermore, if the Potsdam Declaration did not sufficiently clarify the separation of Korea from Japan, then it occurred in practice through the displacement of the Japanese Government-General, the confiscation of all Japanese property in Korea, and the emergence of the South Korean Interim Government (SKIG). ${ }^{59}$ Although USAMGIK recognized that the status of Koreans was yet to be determined, it clearly favored that once a Korean nationality law was formally promulgated, that Koreans in Japan be extended the right to adopt that nationality.

While SCAP continued to treat Koreans in Japan as Japanese nationals, it soon had to contend with the reality of Korean nationality. As USAMGIK prepared for elections to set up a South Korean state, SKIG decided it was necessary to draft comprehensive rules on nationality. SKIG's provisional rules on nationality, enacted on May 11, 1948, stipulated that those who had acquired the nationality of another state were regarded as having recovered their Korean nationality upon renouncing their nationality of foreign states. Although not specifically mentioning Japan, this stipulation promised Koreans that they would recover the Korean nationality that they had lost under Japanese rule. ${ }^{60}$ USAMGIK's Office of Foreign Affairs stated in an internal memo that it pursued a liberal interpretation of these provisional rules to recognize Korean nationality, even though SCAP made no official declarations on the matter. The memo further maintained that "it seems without question that Korean nationals now resident in Japan will have the opportunity for Korean nationality by declaration," 61 just as the State Department's wartime policy proposal had suggested. Once the newly inaugurated ROK government formally promulgated its Nationality Law in December 1948, this would become a matter of diplomatic negotiations between the Korean Mission

59 USAMGIK, Legal Opinions, 376.

60 South Korean Interim Government, "Temporary Provisions Concerning the Law of Nationality" (Public Act No. 11), May 11, 1948. [Record Group 56, NARA]

61 Harold F. Brown, Acting Advisor of OFA, USAMGIK, untitled memo, July 20, 1948. [Record Group 338, Box 69, NARA] 
in Japan and SCAP.

\section{Conclusion}

Examining US policies towards displaced persons in Asia after World War II reveals a critical intersection between postwar and postcolonial history that is distinctive, especially in comparison to Europe. US officials had to contend with the fact that displaced persons in Asia, unlike in Europe, were not simply displaced by the war itself but also by a series of decades-long Japanese colonial policies, complicating the task of postwar repatriation. The consequent uncertainty regarding the status of former colonial subjects was precisely what led to SCAP's ambiguous policy of treating Koreans and Taiwanese as liberated nationals or as enemy nationals, depending on particular circumstances. Whenever they encountered any problems resulting from this policy, occupation officials in Japan steadfastly held that all such issues were best resolved through repatriation. Allied forces in the region thus implemented SCAP's carefully organized plan to return all Japanese and non-Japanese to their respective homelands, reflecting a commitment to separate Japan from its former colonial empire in Asia. In this sense, repatriation played an important role in what Lori Watt calls "third party decolonization," as the Allies triangulated the process of dissolving Japan's empire by placing themselves between the defeated Japanese and liberated Asians. ${ }^{62}$

What complicated this process of American-led decolonization was the policy discord between the two US occupation administrations in Japan and Korea, resulting from their competing jurisdictions and interests. Both tactical and governmental responsibility for US-occupied Korea ultimately rested with General MacArthur, as the Far East Commander, even though he delegated operational control to General Hodge. While

62 Lori Watt, When Empire Comes Home: Repatriation and Reintegration in Postwar Japan (Cambridge: Harvard University Asia Center, 2009), 12, 200. 
USAMGIK authorities including Hodge frequently critiqued SCAP's policies towards Koreans in Japan, they could not challenge the jurisdictional authority of MacArthur's Command. Nevertheless, USAMGIK's Office of Foreign Affairs and its Liaison Offices assumed responsibility for providing assistance and protection to Koreans abroad, at least until the establishment of the ROK. Part of the underlying problem was a clash of attitudes, as William Gane observed that American officers in Japan had become "anti-Korean," because Korean residents so often demonstrated, demanded special treatment, and refused to obey Japanese laws. What these officers failed to understand, according to Gane, was that such acts of civil disobedience resulted from Koreans attempting to ensure their liberation from Japanese colonial oppression. ${ }^{63}$ At a more fundamental level, however, this discord resulted from USAMGIK's insistence on representing Korean interests in Japan that clashed with SCAP's increasing tendency to collaborate with Japanese authorities in suppressing what they viewed as the "Korean problem."

The preferred focus of American occupiers in Japan was on nation building, not on decolonization, a basic stance shared by their counterparts in southern Korea. Unlike USAMGIK, however, SCAP came to believe that all problems emanating from vestiges of Japanese colonialism should be resolved diplomatically on a bilateral basis, and thus the United States as a third party would not interfere in such matters. This was the rationale behind SCAP's reliance on repatriation, which was employed as a convenient mechanism to avoid becoming embroiled in complex postcolonial issues. Such an evasion of decolonization explains SCAP's abandonment of restituting Korean coal miners for their unpaid wages and other assets, despite initially collecting such funds in the SCAP Custody Account. It also explains why SCAP belatedly announced that former colonial subjects in Japan would retain their Japanese nationality, thus pressing Koreans to repatriate in order to attain liberation. Ultimately, US officials agreed with SCAP that a thorough decolonization leading to

63 Gane, "Foreign Affairs of South Korea," 132-133. 
a postcolonial settlement did not serve American interests, which became focused on containing communism in the region. However, the long-term consequences of this cold-war freeze over decolonization soon proved a major impediment for US-mediated efforts to foster closer ties between Japan and South Korea well beyond the normalization of bilateral relations in 1965, resurfacing again as the so-called "history problem" in the 1980s.

\section{References}

1. Augustine, Matthew R., "Restitution for Reconciliation: The US, Japan, and the Unpaid Assets of Asian Forced Mobilization Victims." The Journal of Northeast Asian History 8-1 (Summer 2011)

2. Barkan, Elazar. The Guilt of Nations: Restitution and Negotiating Historical Injustices. New York: W.W. Norton \& Company, 2000.

3. Bix, Herbert P., "Regional Integration: Japan and South Korea in America's Asian Policy." in Without Parallel: The AmericanKorean Relationship Since 1945, edited by Fran Baldwin. New York: Pantheon Books, 1973.

4. Choi, Deokhyo. "Crucible of the Post-Empire: Decolonization, Race, and Cold War Politics in U.S.-Japan-Korea Relations, 1945-1952." PhD diss., Cornell University, 2013.

5. Cheong, Sung-Hwa. The Politics of Anti-Japanese Sentiment in Korea: Japanese-South Korean Relations under American Occupation, 1945-52. Westport: Greenwood Press, 1991.

6. Dower, John W., Embracing Defeat: Japan in the Wake of World War II. New York: W. W. Norton \& Company, 1999.

7. Gane, William J., "Foreign Affairs of South Korea, August 1945 August 1950." PhD diss. Northeastern University, April 1951.

8. Iokibe, Makoto, ed. The Occupation of Japan, Part 1: U.S. Planning Documents, 1942-1945. Congressional Information Service and Maruzen Publishing Co., 1987. 
9. Oliver, Robert T., Why War Came in Korea. New York: Fordham University Press, 1950.

10. Schmid, Andre. "Colonialism and the 'Korea Problem' in the Historiography of Modern Japan: A Review Article." The Journal of Asian Studies 59-4 (November 2000)

11. Takemae, Eiji. Inside GHQ: The Allied Occupation of Japan and its Legacy. New York: Continuum, 2002.

12. Wagner, Edward W., The Korean Minority in Japan, 1904-1950. New York: Institute of Pacific Relations, 1951.

13. Watt, Lori. "Embracing Defeat in Seoul: Rethinking Decolonization in Korea, 1945." The Journal of Asian Studies 74-1 (February 2015)

14. Watt, Lori. When Empire Comes Home: Repatriation and Reintegration in Postwar Japan. Cambridge: Harvard University Asia Center, 2009. 
<Abstract>

\section{The Limits of Decolonization: American Occupiers and the "Korean Problem" in Japan, 1945-1948}

Matthew R. Augustine

Korean and Japanese officials have never engaged in direct negotiations to reach a postcolonial settlement, unlike what followed the breakup of many European colonies. Instead, the problem of how to dissolve Japanese colonialism was indirectly addressed by external mediators; namely, US occupation administrations in Korea and Japan after World War II. Examining the history of third-party decolonization must therefore take into consideration how this process was initially mediated between the new American occupiers in the region. In order to understand how decolonization was compromised in part by evolving and competing American occupation policies, this article examines three interrelated issues that greatly affected Koreans in occupied Japan who found themselves displaced by the sudden collapse of the Japanese empire: repatriation, restitution, and nationality. The extent to which American occupation authorities in Korea and Japan jointly engaged in each of these critical issues vividly illustrates the limits of decolonization.

Keywords: Decolonization, American occupation, SCAP, USAMGIK, repatriation, restitution, nationality, Koreans in Japan. 


\section{〈국문초록〉}

\section{탈식민화의 한계: 주일 미국 점령당국과 일본에서의 “한국인 문제," 1945 1948}

매튜 어거스틴 (규슈대학교 사회문화학부 교수)

유럽 국가들의 식민지 해소 과정과 달리, 한국과 일본 정부는 탈식민 이후의 합 의에 대하여 한번도 직접 협상한 적이 없다. 대신, 일본 식민통치의 해소 문제는 외부의 중개자, 즉 제 2 차 세계대전 이후 한국과 일본의 미국 점령 기구를 통하여 간접적으로 제기되었다. 따라서 제 3 자에 의한 탈식민화 과정에 대한 고찰은 해당 지역의 새로운 점령자인 미국과의 관계에서 어떻게 이 과정을 끌어내었는지를 함 께 고려해야 한다. 제각기 변화하면서 모순적인 미국 점령정책에 의하여 탈식민 화 과정이 절충화되는 과정을 이해하기 위하여, 본 연구는 일본 제국의 갑작스러 운 붕괴에 의하여 내쫓기게 된 재일 조선인들에게 가장 중요했던 배상, 귀환, 국 적 문제를 주목하고자 한다. 이와 같은 중요한 문제에 대한 한국과 일본의 미국 인 점령정부들의 관여의 내용은 탈식민화 과정의 한계를 잘 보여주고 있다.

주제어: 탈식민화, 미국의 일본 점령, 연합군최고사령부, 주한미군정, 귀환, 배상, 국적, 재일조선인 
